\title{
Genetic variability for yield and quality traits in local germplasm of rice of Himachal Pradesh
}

Divya Thakur and Deo Prakash Pandey*

Rice and Wheat Research Centre, CSKHPKV, Malan-176 047, HP

Article history: Received: 19 July., 2020 Revised: 15 Aug., 2020 Accepted: 16 Aug., 2020

Citation: Thakur Divya and DP Pandey 2020. Genetic variability for yield and quality traits in local germplasm of rice of Himachal Pradesh. Journal of Cereal Research 12(2): 157-159. http:// doi.org/10.25174/2582-2675/2020/'103761

*Corresponding author: E-mail: pandeydp04@yahoo.co.in

(C) Society for Advancement of Wheat and Barley Research

Keywords: Rice, genetic varability, local germplasm, yield traits

Rice (Oryza sativa L. 2n: 2x: 24) is the most important cereal crop cultivated widely in many parts of the world. Rice is grown under various agro-climatic conditions thus having greater variability in the local germplasm so, there is need to evaluate local germplasm adapted to H.P. for further use in breeding programme. Sufficient genetic variability, if present, can be exploited for developing superior cultivars. According to Fisher (1918), continuous variation exhibited by a quantitative characters, includes the heritable and non-heritable component. Wright (1921) reported that heredity component comprised of additive and non-additive portion and former responds to the selection.

Forty five diverse genotypes of rice from different geographical origin in H.P. were transplanted in 3 replications with in $\mathrm{RBD}$ design at Rice and Wheat Research Centre, Malan, HP during Kharif ,2018. In each replication, single seedling was transplanted per hill in 4 rows with $20 \times 15 \mathrm{~cm}$ spacing.

The observations were recorded on five randomly taken plants from each plot for days to 50 per cent flowering, days to 75 per cent maturity, plant height at maturity, total tillers/plant at maturity, effective tillers/plant at maturity, grain yield/plant, spikelets/panicle, grains/panicle, panicle length, 1000-grain weight, spikelet fertility, kernel elongation, grain length (L), grain breadth (B), length breadth ratio $(\mathrm{L}: \mathrm{B})$, gel consistency $(\mathrm{GC})$, gelatinization temperature (GT) rating, protein content and amylose content. Analysis of variance was carried out as suggested by Panse and Sukhatme (1978) GCV and PCV were carried out as per the methods suggested by Burton (1952) Heritability (BS) and Genetic Advance were estimated by using the formula suggested by Burton and Devane (1953).
Analysis of variance revealed that significant differences existed among the genotypes for all the characters studied. (Table 1\&2). A perusal of genetic parameters revealed that phenotypic and genotypic coefficients of variation were high for GC. Moderate for plant height, total tillers/ plant, effective tillers/plant, grains/panicle, spikelets/ panicle and grain yield/plant and low PCV and GCV was recorded for rest of traits. Results were in accordance with Shrivastava et al., (2015), Panwar (2005), Seyoum et al., (2012), Devi (2015) Shashidhara (2017).

High heritability (Table 3 ) coupled with high genetic advance was observed for GC. High heritability coupled with moderate genetic advance was observed by days to 50\% flowering, plant height, grains/panicle, spikelets/ panicle, L:B ratio, and GT. Depicting these traits were controlled by additive gene effects thus selection for these traits will be effective. Grain yield showed moderate heritability coupled with low genetic advance. High heritability with low genetic advance was depicted by characters panicle length, 1000-grain weight, amylose content and protein content indicating that character is governed by non-additive genes and heterosis breeding may be useful here. Low heritability coupled with low genetic advance was shown by spikelet fertility. These findings were in confirmation with the results of Panwar (2005), Lingaiah et al., (2018), Rukmani et al., (2016), Singh et al., (2006), Abebe et al., (2017), Prabhu et al.,(2017), Dutta et al., (2016), and Pang et al., (2016).

Analysis of variation showed significant differences among all the genotypes for all the traits suggesting prevalence of wide range of genetic variability and scope of selection for these traits. Estimates of variability revealed that plant height, total tillers/plant, effective tillers/plant, panicle 


\section{Journal of Cereal Research}

Table 1: Analysis of variance for yield and morphological traits

\begin{tabular}{|c|c|c|c|c|c|c|c|c|c|c|c|}
\hline $\begin{array}{l}\text { Source of } \\
\text { Variation }\end{array}$ & $\mathrm{df}$ & $\begin{array}{l}\text { Days to } \\
50 \% \text { flowe } \\
\text { ring }\end{array}$ & $\begin{array}{l}\text { Days to } \\
75 \% \\
\text { maturity }\end{array}$ & $\begin{array}{l}\text { Plant } \\
\text { height } \\
(\mathrm{cm})\end{array}$ & $\begin{array}{l}\text { Total } \\
\text { tillers/ } \\
\text { plant } \\
\text { at } \\
\text { matur } \\
\text { ity }\end{array}$ & $\begin{array}{l}\text { Effective } \\
\text { tillers/ } \\
\text { plant at } \\
\text { maturity }\end{array}$ & $\begin{array}{l}\text { Panicle } \\
\text { length } \\
(\mathrm{cm})\end{array}$ & $\begin{array}{l}\text { Grains } \\
\text { /panicle } \\
\text { (Nos.) }\end{array}$ & $\begin{array}{l}\text { Spikelets } \\
\text { /panicle } \\
\text { (Nos.) }\end{array}$ & $\begin{array}{l}\text { Grain } \\
\text { yield/ } \\
\text { plant(g) }\end{array}$ & $\begin{array}{l}\text { 1000-grain } \\
\text { weight }(\mathrm{g})\end{array}$ \\
\hline Replication & 2 & 1.43 & 10.14 & 18.53 & 1.62 & 2.02 & 3.77 & 96.83 & 93.96 & 31.39 & 92.99 \\
\hline Treatment & 44 & $78.34^{*}$ & $11.35^{*}$ & $1208.24^{*}$ & $2.72^{*}$ & $2.68^{*}$ & $31.77^{*}$ & $2364.39^{*}$ & $2723.30^{*}$ & $23.38^{*}$ & $45.08^{*}$ \\
\hline Error & 88 & 1.53 & 1.43 & 19.19 & 0.26 & 0.32 & 0.89 & 66.57 & 134.93 & 3.60 & 3.73 \\
\hline
\end{tabular}

*Significant at 5\% level

Table2: Analysis of variance for quality traits

\begin{tabular}{|c|c|c|c|c|c|c|c|c|c|c|}
\hline $\begin{array}{l}\text { Source of } \\
\text { Variation }\end{array}$ & $\mathrm{df}$ & $\begin{array}{l}\text { Grain } \\
\text { length } \\
(\mathrm{mm})\end{array}$ & $\begin{array}{l}\text { Grain } \\
\text { breadth } \\
(\mathrm{mm})\end{array}$ & \begin{tabular}{l} 
Length \\
Breadth \} $\\
{\text { ratio (L:B) }}$ & $\begin{array}{l}\text { Kernel } \\
\text { elongation } \\
(\mathrm{mm})\end{array}$ & $\begin{array}{l}\text { Spikelet } \\
\text { fertility }(\%)\end{array}$ & $\begin{array}{l}\text { Gel consistency } \\
(\mathrm{mm})\end{array}$ & $\begin{array}{l}\text { Gelatinization } \\
\text { temperature } \\
\text { rating }\end{array}$ & $\begin{array}{l}\text { Amylose } \\
(\%)\end{array}$ & Protein $(\%)$ \\
\hline Replication & 2 & 0.113 & 0.020 & 0.024 & 0.24 & 9.65 & 4.58 & 0.59 & 0.02 & 0.12 \\
\hline Treatment & 44 & $1.244^{*}$ & $0.137^{*}$ & $0.582^{*}$ & $1.74^{*}$ & $72.76^{*}$ & $734.85^{*}$ & $4.22^{*}$ & $16.42^{*}$ & $1.91^{*}$ \\
\hline Error & 88 & 0.109 & 0.013 & 0.027 & 0.13 & 16.36 & 0.99 & 0.28 & 0.10 & 0.02 \\
\hline
\end{tabular}
\end{tabular}

*Significant at 5\% level

Table 3: Estimates of parameters of variabilityfordifferent traits in rice genotypes

\begin{tabular}{|c|c|c|c|c|c|c|}
\hline Traits & Mean & Range (min-max) & $\operatorname{PCV}(\%)$ & $\operatorname{GCV}(\%)$ & $\begin{array}{l}\text { Heritability } \\
\text { broad sense h2bs } \\
(\%)\end{array}$ & $\begin{array}{l}\text { GA as percentage } \\
\text { of mean }\end{array}$ \\
\hline Days to $50 \%$ flowering & 90.70 & $78.00-100.33$ & 5.74 & 5.58 & 94.37 & 11.16 \\
\hline Days to $75 \%$ maturity & 123.37 & $120.33-129.00$ & 1.76 & 1.47 & 69.84 & 2.54 \\
\hline Plant height (cm) & 129.00 & $89.67-159.47$ & 15.80 & 15.43 & 95.39 & 31.05 \\
\hline Total tillers/plant & 5.10 & $3.73-7.60$ & 20.34 & 17.75 & 76.13 & 31.90 \\
\hline Effective tillers/plant & 4.99 & $3.40-7.53$ & 21.10 & 17.78 & 71.01 & 30.87 \\
\hline Panicle length $(\mathrm{cm})$ & 25.80 & $20.77-31.77$ & 12.96 & 12.43 & 92.03 & 24.57 \\
\hline Grains /panicle & 134.08 & $79.33-195.10$ & 21.52 & 20.64 & 92.00 & 40.79 \\
\hline Spikelets/panicle & 149.91 & $82.27-211.60$ & 21.07 & 19.59 & 86.48 & 37.54 \\
\hline Grain yield/plant (g) & 19.00 & $13.30-26.43$ & 16.81 & 13.52 & 64.67 & 22.39 \\
\hline 1000- grain weight $(\mathrm{g})$ & 33.17 & $24.83-40.87$ & 12.62 & 11.19 & 78.68 & 20.45 \\
\hline Grain length $(\mathrm{mm})$ & 6.68 & $5.43-7.73$ & 10.44 & 9.21 & 77.70 & 16.72 \\
\hline Grain breadth (mm) & 2.29 & $1.77-2.70$ & 10.17 & 8.83 & 75.37 & 15.79 \\
\hline $\mathrm{L}: \mathrm{B}$ ratio & 2.95 & $2.03-4.07$ & 15.62 & 14.58 & 87.09 & 28.02 \\
\hline Kernel elongation (mm) & 8.96 & $7.30-10.60$ & 9.11 & 8.20 & 80.95 & 15.19 \\
\hline Spikelet fertility $(\%)$ & 89.20 & 78.33-96.63 & 6.65 & 4.86 & 53.46 & 7.32 \\
\hline Gel consistency (mm) & 45.43 & 23.33-86.33 & 34.50 & 34.43 & 99.60 & 70.78 \\
\hline Gelatinization temperature (rating) & 4.48 & $2.33-7.67$ & 28.18 & 25.57 & 82.31 & 47.78 \\
\hline Amylose (\%) & 22.54 & $18.30-28.90$ & 10.44 & 10.35 & 98.29 & 21.14 \\
\hline Protein $(\%)$ & 8.39 & $6.53-10.27$ & 9.63 & 9.46 & 96.54 & 19.15 \\
\hline
\end{tabular}


length, grains/panicle, spikelets/panicle, L:B ratio ,GC and GT exhibited high to moderate heritability coupled with high to moderate genetic advance thus depicting these traits were controlled by additive gene effects thus selection for these traits will be effective. Grain yield showed moderate heritability coupled with low PCV, GCV and genetic advance. Moderate PCV and GCV was observed for days to grains/panicle, spikelets/panicle and $\mathrm{L}: \mathrm{B}$ ratio, which indicated the presence of additive gene action and sufficient variability scope for improvement through selection.

\section{References}

1. Abebe T, S Alamerew and L Tulu. 2017. Genetic variability, heritability and genetic advance for yield and its related traits in rainfed lowland rice (Oryza sativa L.). Genotypes at Fogera and Pawe, Ethiopia 5: 1-8

2. Burton, GW 1952. Quantitative inheritance in grasses. Proceedings of 6 th International Grassland Congress 1 : 227-283

3. Burton GW and EW De Vane, 1953. Estimating heritability in tall fescue (Festuca arundinacea) from replicated clonal material. Journal of Agronomy 45: $478-481$

4. Devi GN, VR Babu, G Padmavathi and T Sunitha. 2015. Genetic diversity in grain quality traits of rice genotypes. Journal of Rice Research 8: 1-3

5. Dutta BC, A Nath and T Dasgupta 2016. Characterization and variability analysis of rice genotypes with refrence to cooking quality parameters. Journal of Agriculture and Veterinary Science 9(4): 8-12

6. Fisher RA. 1918. The correlation between relatives on the supposition of Mendelian inheritance. Royal Society Edinburgh 52: 399-433

7. Lingaiah N, S Neelamraju, V Venkanna, D Reddy and RC Surender 2018. Variability studies in F2 population of rice. International Journal of Agriculture Science 10(9): 5956-5957

8. Pang Y, J Ali, X Wang, NJ Franje, JE Revilleza, J Xu and $\mathrm{Z} \mathrm{Li} \mathrm{2016.} \mathrm{Relationship} \mathrm{of} \mathrm{rice} \mathrm{grain} \mathrm{amylose,}$ gelatinization temperature and pasting properties for breeding better eating and cooking quality of rice varieties. Plos one 1-16

9. Panse VG and PV Sukhatme 1985. Statistical Methods for Agricultural Workers. ICAR, New Delhi PP:359

10. Panwar LL. 2005. Genetic variability, heritability and genetic advance for panicle characters in transplanted rice. Research On Crops 6: 505-508

11. Prabhu SM, Meenakshi Ganeshan N, Jayaprakash $\mathrm{P}$ and R Selvakumar 2017. Assessment of genetic variability and heritability in segregating populations. International Journal of Agricultural Science and Research 7(3): 267-270

12. Rukmini K, K Parimala, V Venkanna, N Lingaiah, Y Hari and BC Chandra 2016. Estimation of variability for grain yield and quality traits in rice (Oryza sativa L.). International Journal of Pure and Applied Bioscience 4(2): 250-255

13. Seyoum M, S Alamerew and K Bantte 2012. Genetic variability, heritability, correlation coefficient and path analysis for yield and yield related traits in Rice (Oryza sativa L.) Journal of Plant Sciences 7: 13-22

14. Shashidhara N, H Biradar and S Hittalmani 2017. Qualitativeand quantitative genetic variations in F2 inter varietal cross of rie (Oryza sativa $\mathrm{L}$.) under aerobic condition and polymorphism survey. International Journal of Current Microbiology and Applied Sciences 6(4): 2215-2225

15. Shrivastava A, DK Mishra and GK Koutu 2015. Estimation of genetic parameters of variability for yield and its attributing traits in parental lines of hybrid rice. Plant Archives 15(1): 571-574

16. Singh SP, RP Singh, K Srinivasulu and JP Prasad 2006. Studies on genetic variability, character association in diverse lines of international irrigated observation nursery of rice. Research On Crops 7: 714-719

17. Wright S. 1921. Correlation and causation. Journal of Agricultural Research 20: 557-585 